\title{
India, Indonesia, Australia ke Tiongkok: Sebuah Studi Mengenai Konsep Sphere of Influence di Era Kontemporer
}

\author{
Lazarus Andja Karunia \\ Undergraduate Student of International Relations Department at Universitas Gadjah Mada \\ lazarusandjakarunia@gmail.com
}

\begin{abstract}
Abstrak
Abad ke-21 mendekati akhir dekade keduanya. Polaritas dunia masih terlihat condong ke Washington walaupun banyak yang merasa kekuatan Beijing akan menandinginya. Di lain pihak, kita tidak bisa melupakan reaksi dan strategi para regional power di jalur ekspansi Belt and Road Initiative Tiongkok. New Delhi, Jakarta dan Canberra sudah mulai menunjukkan keinginan mereka untuk bersatu menangkal ekspansi Beijing setidaknya setahun terakhir ini. Pembahasan yang dibawa akan sesekali berfokus pada bagaimana konsep regional hegemony, structural realism, dan sphere of influence pada saat ini sedang digunakan oleh ketiga regionalpower terutama dalam menangkal ekspansi Tiongkok di Laut Natuna Utara. Regional hegemony akan menjelaskan pada kadar tertentu 'kedaulatan regional' ketiga negara, structural realism akan menjelaskan alasan realis ketiga negara untuk bersatu, dan sphere of influence akan menjelaskan mengapa proyeksi regionalisme ketiga negara dieksekusi secara terbatas. Riset ini akan mengupas tiga pertanyaan. Mengapa ketiga negara mau bekerja sama? Apakah tiap negara memiliki kontribusi efektif terhadap tujuan mereka bersama?
\end{abstract}

\section{Historical Hegemons: An Introduction}

India, Indonesia, and Australia has been the prominent country in their respective regions. India has always been seen as one of those prominent country considering their significant number of population, their large territory, and their massive economy. Indonesia on the other hand, was an understandable danger during their early years with a large territory, Soviet influence, and an aggressive leader at the helm. Australia is still commonly 
seen as the deputy marshall to the influence of the United States in the surrounding area even though lately their economic influence, cooperation with the US, and humanitarian interventions in the region has been challenged. ${ }^{1}$ Their prominence can be argued to be constantly under fire whether by rival countries, a hampering regional procedure, or an incoherent distant ally. This paper will focus specifically on how all of those problems are adding more stress to the ever looming threat of chinese influence to the three countries. By way of security, economy, politics, or military, Beijing has posed quite a significant threat to their regional prominence. South Asia, Southeast Asia, and the Pacific has their respective hegemon preparing and the three of them has proposed a triage of cooperation to counter China.

South Asia most of the time has seen the contestation of powers between Pakistan and India. At their births, during the cold war, during their acquisition of nuclear weapons, and even in the 21 st century, their rivalry was coloring the politics of South Asia in their unique way. Even though Ali Jinnah wanted an at least peaceful relation between the two, his succeeding colleagues fail or was not in favor in safeguarding Jinnah's vision to fruition. Instead we kept on seeing skirmishes in Jammu and Kashmir, frequent anti-India rhetoric in Pakistani elections, ${ }^{2}$ to the general failure of SAARC in stimulating regional cooperation and trade. ${ }^{3}$ Perhaps that situation then gave the output of being one of the regions in the world without proper regionalism in place. ${ }^{4}$

Southeast Asia on the other hand, has a very different geopolitical situation. This is due to the fact that the region is comprised of the mainland area and the string of archipelagoes called the insular Southeast Asia. ${ }^{5}$ The mainland area is comprised of various states such as Cambodia, Laos, Myanmar, and Thailand while the insular - archipelagic area is almost fully comprised of Indonesian territory. ASEAN's establishment was seen by many as a miracle in the region considering the many differing political, religious, and social views

\footnotetext{
${ }^{1}$ Joanne Wallis, "Hollow hegemon: Australia's declining influence in the Pacific," East Asia Forum, 21 September, 2016, http://www.eastasiaforum.org/2016/09/21/hollow-hegemon-australias-declining-role-in-thepacific/.

2 "'Any friend of Modi's is a traitor': Anti-India rhetoric played a role in Pakistan elections," scroll.in, https://scroll.in/article/888135/any-friend-of-modis-is-a-traitor-the-role-anti-india-rhetoric-played-in-pakistanselections.

3 Jawad Falak, "Implacable Failures of the SAARC," Center For Strategic and Contemporary Research, 21 June, 2017, https://cscr.pk/explore/themes/politics-governance/implacable-failures-of-the-saarc/.

${ }^{4}$ Partha S Ghosh, "Cooperation in South Asia: Region without Regionalism," Economic \& Political Weekly, 6 August, 2018, https://www.epw.in/journal/2016/32/special-articles/region-without-regionalism.html.

${ }^{5}$ William H. Frederick and Thomas R. Leinbach, "Southeast Asia," Encyclopaedia Britannica, https://www.britannica.com/place/Southeast-Asia.
} 
in its member states. This is also considering that before the establishment of ASEAN, there are a notable amount of conflicts in the region such as the Burmese-Siamese wars, the First Indochina war, and the Indonesia-Malaysia Confrontation. The sheer size of Indonesia and the looming threat of its gigantic opportunity prompted some scholar to argue that ASEAN was made also in part to contain Indonesia 's possibility to be the big and tyrannical member state through its consensus-based mechanism. ${ }^{6}$

Oceania and the Pacific possess the might of the Commonwealth of Australia that can be argued to have the similar strength of the United States. Australia can be seen to have provided ample interventions in the region such as during the Vietnam war and the First Malayan Emergency. Not to mention that Australia has ANZAC and ANZUS that shields the region with a significant amount of military power. This could in turn contribute to the accumulation of Australia's capacity to provide humanitarian intervention to those countries in need, particularly in Southeast Asia, Oceania, and the Pacific. Australia was quite recently even mentioned to have the possibility to join ASEAN. ${ }^{7}$ Even though many scholars view the invitation to be a mere good gesture, it is still an exemplar to their diplomatic capability, or their skills in maintaining good relations with their northern neighbors. ${ }^{8}$

The three countries' common threat, China, was historically taking several consecutive pivotal events throughout their days. From the catastrophe of the Great Leap Forward, their civil war against the Kuomintang for the domination of the Communist Party, and the Sino-Soviet split. The turning point is believed to come from the 1970s according to several scholars, in regards to their market reforms. ${ }^{9}$ Their stable market improvement over the decades, the fall of the Soviet Union, the end of the Cold War, and also the continuing decline of America's unipolar moment can be argued to be some of the factors to contribute to their rise. ${ }^{10}$

Before delving further it is important to explain what china's Belt and Road Initiative is. Firstly, the BRI is a series of investment plans to bring stimulus to several countries with

\footnotetext{
${ }^{6}$ Nik Luqman, "Is ASEAN Consensus A Blessing or Curse - or Both?," ASEAN News, 19 July, 2015, http://www.aseannews.net/asean-consensus-blessing-curse/.

7 “Pertama Kali, Presiden Jokowi Dukung Australia Masuk ASEAN," Tempo.co, 16 March, 2018, https://dunia.tempo.co/read/1070224/pertama-kali-presiden-jokowi-dukung-australia-masuk-asean. ${ }^{8}$ Angaindrakumar Gnanasagaran, "Behind Australia's invitation to join ASEAN," The ASEAN Post, 19 March, 2018, https://theaseanpost.com/article/behind-australias-invitation-join-asean.

${ }^{9}$ G. John Ikenberry, "The Rise of China and the Future of the West," Foreign Affairs, February, 2008, https://www.foreignaffairs.com/articles/asia/2008-01-01/rise-china-and-future-west.

${ }^{10}$ Kevin Rudd, "Are China and the US doomed to conflict? | Kevin Rudd -YouTube," TED, 1 April, 2015, https://www.youtube.com/watch?v=8XQ1onjXJK0.
} 
slowing economies. ${ }^{11}$ It also covers the cooperation between Beijing and several other countries in materializing their infrastructure projects whether it is making fibre optic wires for internet, building ports, or naval bases. All of these efforts can be argued to be the main mission in China's peaceful rise concept in gaining global hegemony. This is of course welcomed with United States resistance towards this contestation of the status quo.

Funnily enough, the three countries also have a common ally, which is the United States. It is important to note that each of the countries have different levels and extent of friendship towards the United States, with arguably minimum commonalities in regards to their similarities in international relations with the United States. For example, India goes way back from their Cold War Non-Aligned Movement stance which was frowned upon to a certain extent by some United States officials, their complications during the Bangladeshi independence struggle in 1971, to their current standing which is being the second largest trading partner of the United States. Indonesia has a different story, which was painted with hatred towards western countries in regards to their imperialism, then changed with a New Order regime which was favoring the United States, to its current political climate in which the citizens view the United States as the prime example of greedy developed states. Australia can be argued to be the only state with the most consistent relations with the United States, even though recently they have to carefully thread with Washington regarding several issues about China. ${ }^{12}$

With all of that said, the subsequent discussion shall encompass the dissection of the chinese maneuvers, regional hegemonic obstacles, and possible points of opportunities to assist by the other two countries. It would also to a certain extent, seek to observe the triage's contribution to the United States' efforts to counter chinese hegemonism in Asia.

\section{The Three Leviathans}

\section{Part One: New Delhi's Political Gap}

The Republic of India can be argued to get disturbances from Beijing mainly from their precision maneuvers towards its neighbors. Namely towards Pakistan, Maldives, and

\footnotetext{
${ }^{11}$ Lily Kuo and Niko Kommenda, "What is China's Belt and Road Initiative?," The Guardian, https://www.theguardian.com/cities/ng-interactive/2018/jul/30/what-china-belt-road-initiative-silk-roadexplainer.

12 “Australia warns against US-China tensions," The Strait Times, 1 November, 2018, https://www.straitstimes.com/asia/australianz/australia-warns-against-us-china-tensions.
} 
towards the overall region. ${ }^{13}$ In a region without regionalism, contested hegemonism with Pakistan, and an overall low intra-regional trade, India must race against the increase of China's influence in the region. ${ }^{14}$ Interestingly, China made an arguably mutually beneficial cooperation with Pakistan, while arranging a detrimental agreement with Maldives which would potentially engulf the country with chinese debt for years to come. ${ }^{15}$

With the case of South Asia, China has been increasingly cooperating with the Islamic Republic. One example can be taken from their endeavor to construct the China-Pakistan Economic Corridor to connect China's city of Kashgar with the Pakistani Gwadar port which are 3,000 kilometers away. ${ }^{16}$ This is of course part of the Belt and Road Initiative that goes through South Asia. Maldives on the other hand, is in a dire situation due to their agreement of debt acquisition from Beijing. It is noted that Maldives' foreign debt that is owed to China is over 70 percent with loan intetest that is more than 20 percent of their budget. ${ }^{17}$ Another danger in the region can be seen in how Nepal is also pursued by China's grip by their internet infrastructure cooperation with fibre optic cables from Beijing according to an analysis by the Centre for China Analysis \& Strategy. ${ }^{18}$ The same document also mentions how India's approach is portrayed by Chinese military media as expansionist and prone to interfering their neighbors' domestic affairs.

India's hegemonically regional response can be argued to be hampered by several things. One of which is of course Pakistan, and also the currently low intra-regional trade. Pakistan's hegemonic contestation with India in regards to South Asian leadership is tipped due to Chinese cooperation with Pakistan. The low intra-regional trade might also contribute to the hardships that India faces in combating the increase of Chinese investment and trade in the country. With that said, those are two of the contributing factors to challenge Indian hegemonic influence in the region.

\footnotetext{
${ }^{13}$ Zee Ayurveda, "After China, maldives ropes in Pakistan for Power," The Times of India, 6 July, 2018, https://timesofindia.indiatimes.com/world/south-asia/after-china-maldives-ropes-in-pakistan-forpower/articleshow/64889956.cms.

14 "The Potential of Intra-regional Trade for South Asia," The World Bank, 24 May, 2018, http://www.worldbank.org/en/news/infographic/2016/05/24/the-potential-of-intra-regional-trade-for-south-asia. ${ }^{15}$ Sanjeev Miglani and Mohamed Junayd, "After building spree, just how much does the Maldives owe China?," Reuters, 23 November, 2018, https://www.reuters.com/article/us-maldives-politics-china/afterbuilding-spree-just-how-much-does-the-maldives-owe-china-idUSKCN1NS1J2.

${ }^{16}$ Mercy A. Kuo, "China-Pakistan Relations: Challenging US Global Leadership," The Diplomat, 30 May, 2018, https://thediplomat.com/2018/05/china-pakistan-relations-challenging-us-global-leadership/.

${ }^{17}$ Jayadeva Ranade, "SITUATION IN MALDIVES COULD POTENTIALLY FURTHER RAISE INDIACHINA TENSIONS," Centre for China Analysis \& Strategy, 19 February, 2018, https://ccasindia.org/Maldives.pdf. ${ }^{18}$ Ibid.
} 
Islamabad has repeatedly try to counterbalance New Delhi in regards to leadership in the region. Some scholars have noted that Pakistan is executing a maneuver of area of denial to cut the access and movement of India towards accomplishing economic and military means. ${ }^{19}$ Over the course of their rivalry, several acts of terrorism are even permitted by each sides as long as it undermines the power of the other. This is in the sense of turning the other way when these acts are conducted.

Another challenge is the low intra-regional trade. An analysis done by the Centre for Strategic and Contemporary Resereach found this can be correlated to the failure of the South Asian Association for Regional Cooperation's (SAARC) lack in their ability to promote intraregional cooperation and connectivity. Their intra-regional trade is only at 5 percent and their member states have low ranking on the human development index. The document also stated how both the Indo-Pakistan rivalry and the lack in infrastructure to connect member states is the main reason for this detrimental fact. ${ }^{20}$

Seeing all of these obstacles and challenges, India may face them alone, but I believe that Indonesia and Australia's contribution towards countering chinese influence can further give strength to their collective efforts. I believe that India's economic success in recent times will be able to counter China's economic influence although not in a completely symmetrical way against their Belt and Road Initiative. Through India's practice of increased intraregional trading, further cooperation might be achieved over time.

India has indeed tried to demolish trade barriers, make free trade agreements, and intensify trade intra-regionally, but New Delhi has to keep maintaining the pace if it wishes to widen the gap between Beijing's trading activity intensity in South Asia and theirs. India has however tried to intensify relations with its neighboring countries courtesy of Narendra Modi's neighborhood first and Act East Policy. We can see that India tries to boost its relations with its closest neighbors like Nepal and Sri Lanka in order to maintain the image of the benevolent regional hegemon. ${ }^{21}$ Those efforts needs to be observed closely if India wishes

\footnotetext{
${ }^{19}$ Jawad Falak, "INDIAN HEGEMONY: ROOTS OF SOUTH ASIAN CONFLICT," Strategem, 2016, http://www.stratagem.pk/setting-the-record-straight/indian-hegemony-roots-south-asian-conflict/.

20 "Implacable Failures of the SAARC," Centre for Strategic and Contemporary Research, 21 June, 2017, https://cscr.pk/explore/themes/politics-governance/implacable-failures-of-the-saarc/.

21 "PM Narendra Modi's visit a grand success, says Sri lanka minister," Hindustan Times, 17 May, 2017, https://www.hindustantimes.com/india-news/pm-narendra-modi-s-visit-a-grand-success-says-sri-lankaminister/story-4rair1RfTsAkocLVPeAG8N.html.
} 
to improve its structural architecture in SAARC in the pursuit of regional stability and to give positive effect to its own sphere of influence.

Other aspects however, can be helped by Indonesia and Australia. This is in the sense that because of the maritime and land structure of the BRI, Indonesia and Australia may help east chinese efforts by way of the sea. This is in the sense that they can help in maintaining the laws of the sea in the South China Sea, and in a way would keep a portion of chinese attention away from South Asia. Indonesia can help in the sense that it can give an opposition towards Beijing in its regional ASEAN setting, while Australia can keep a strategic presence in the area to keep chinese expansion in check by displaying Australian regional power in its military joint training. ${ }^{22}$

\section{Part Two: Canberra's Deputy Duty}

Australia as already been stated, has been commonly referred to be the deputy of the United States. In Canberra's case, the problem is not in an endeavor to maintain hegemonic powers and presence, but to maintain a balance in economic cooperation and keeping a political primacy. ${ }^{23}$ We see that to be consistent with the demands and vision of the United States is not longer an emphasis for the Australian government after their change of leadership. Prime Minister Scott Morrison has expressed publicly that he is in line and sure of the intent of the United States in regards to their foreign policy. He even remarked on how to a certain extent, he understands how Trump views the globalized economy as taking a toll on some percentage of the world population. ${ }^{24}$

Scott Morrison and his past actions speak loud when we want to know his stance on dealing with the chinese. During his term as Acting Home Affairs Minister, he banned Huawei's $5 \mathrm{G}$ technology to enter australia out of national security concerns. ${ }^{25}$ The next example would be when he held the title of treasurer and blocked the attempted purchase of $S$ Kidman \& Co. by a Chinese consortium out of concerns that the foreign nature of the buyer

\footnotetext{
22 "Australian Military in South China Sea," SBS NEWS, 1 October, 2018, https://www.sbs.com.au/news/australian-military-in-south-china-sea.

${ }^{23}$ Wang Xiangwei, “ANTI-CHINA HYSTERIA VS NEED FOR TRADE: AUSTRALIA STRUGGLES WITH A RISING BEIJING,” South China Morning Post, 4 August, 2018, https://www.scmp.com/weekasia/opinion/article/2157933/anti-china-hysteria-vs-need-trade-australia-struggles-rising. 24 "'I think we both get it': Scott Morrison professes admiration for Trump," The Guardian, 17 September, 2018, https://www.theguardian.com/australia-news/2018/sep/17/i-think-we-both-get-it-scott-morrisonprofesses-admiration-for-trump.

25 "Huawei and ZTE handed 5G network ban in Australia," BBC News, 23 August, 2018, https://www.bbc.com/news/technology-45281495.
} 
would be contrary to national interest. ${ }^{26}$ Other than that, he also rejected the bid by two Chinese companies in the sale of Ausgrid, the country's biggest power grid, out of security concerns. ${ }^{27}$ So we can see here that standing still and pushing back against chinese influence is not an alien act for Scott Morrison.

Australia has even planned to make a naval base in Papua New Guinea to counter China's influence in the pacific. ${ }^{28}$ Scott Morrison has stated that, "the Pacific is a very highpriority area of strategic national security interest for Australia," in the elaboration of the plan. Another plan announced this past year has also taken place to formulate a security treaty with Vanuatu with the similar agenda of thwarting chinese expansion in the region. ${ }^{29}$

Perhaps the obstacle for Australia in this regard would be in strengthening its ties with its northern neighbors in ASEAN. Australia's close relation with the United States make it obliged to exemplify a similar stance. This obligation to imitate makes it difficult for Australia to not be considered as an outsider in Southeast Asia particularly when discussing the security aspect of the South China Sea. Recalling that ASEAN member states have different views on justifying or defying chinese influence in the area, Australia might have a hard time in maintaining good relations with the regional institution of ASEAN as the closest political structure in the region.

The triage here might be able to help Australia in maintaining a strategic balance in their relations with China and ASEAN, which is through Indonesia. We can argue that Indonesia, as one of the prominent countries in ASEAN can in fact provide arguments and rationale to the rest of ASEAN to include Australia in handling the South China Sea dispute. We can argue that India might also be of help in the sense of keeping the strategic partnership close with Australia in the future. The trade partnership between India and Australia might be

\footnotetext{
${ }^{26}$ Coco Feng, Qing Ying, Zeng Jia, Wang Liwei, "New Australian PM Has History of Blocking Chinese Investment," Caixin Global, 24 August, 2018, https://www.caixinglobal.com/2018-08-24/new-australian-pmhas-history-of-blocking-chinese-investment-101318546.html.

${ }^{27}$ Ibid.

28 "Australia plans naval base in Papua New Guinea to curb China's Pacific Influence," South China Morning Post, 20 September, 2018, https://www.scmp.com/news/asia/australasia/article/2164982/australia-plans-navalbase-papua-new-guinea-curb-chinas.

29 "Australia and Vanuatu to negotiate security pact to head off China expansion," The Telegraph, 22 June 2018, https://www.telegraph.co.uk/news/2018/06/25/australia-vanuatu-negotiate-security-pact-head-china-expansion/.
} 
apt for Canberra in maintaining a strong standing against the tide of chinese economic influence just from looking at the past year's trade activities alone. ${ }^{30}$

To summarize, Indonesia is more apt in providing political assistance in the multilateral setting of the South China Sea dispute, while India is at a better capacity to provide Australia the necessary economic cooperation needed to sustain a prolonged attempt at countering chinese influence in their region with respect to this new Trilateralism. With Australia's close relations with the United States, the triage might have more military firepower if it comes to it.

\section{Part Three: Jakarta, the Giant in Bondage}

Indonesia, as one of the leading actors in Asia, especially in the Southeast region, also has a lot to say in the matter. Of course, one of the movement by China that is clashing with Indonesia's interest has to be the South China Sea dispute. Another would be China's rapid investment that is being poured to various Indonesian infrastructure projects all over the country. This prompts Indonesia to have the need to balance their encounter and relations with China in the sense that they want to maintain themselves to not be engulfed by foreign dominance.

The South China Sea dispute has been going on for a while and it has split the Southeast Asian or ASEAN bloc. The split comes in the various forms of support or denial for chinese presence in the area. One significant shift is the change of stance from the government of the Phillipines after Rodrigo Duterte took power. ${ }^{31}$ The significance comes also from the fact that one of the recent chairmanship for ASEAN was held by the Philippines, thus Duterte's distaste for the United States might complicate the ASEAN Centrality that is currently being built by the regional bloc. That is also compounded by the overlapping claims by various member states in the area. The overlap thus convolutes any attempt at making a solution to counter chinese military expansion in South China Sea.

\footnotetext{
${ }^{30}$ Kirtika Suneja, "Australia committed to concluding a high-quality FTA with India, says Australian High Commissioner," The Economic Times, 8 August, 2018,

https://economictimes.indiatimes.com/news/economy/foreign-trade/australia-committed-to-concluding-a-highquality-fta-with-india-says-australian-high-commissioner/articleshow/65328506.cms.

${ }^{31}$ Andreo Calonzo, "'I Need China': Duterte's Pivot to Beijing Shows Signs of Payoff," Bloomberg, 12 April, 2018, https://www.bloomberg.com/news/articles/2018-04-11/duterte-s-pivot-to-china-shows-some-signs-ofeconomic-payoff.
} 
The second issue encompass the seemingly unending financial penetration by Beijing towards Indonesia's infrastructure building. Out of 33 Indonesian infrastructural projects that can be argued to be strategically beneficial for BRI, 14 of them are already in the planning stage. ${ }^{32} \mathrm{We}$ can see how this would be troublesome in maintaining limited dependence amongst foreign investment. On the other hand you have a need for infrastructure, but also to maintain a significant amount of people employed. This is problematic in the reality that many chinese projects employ their own citizens in Indonesia. ${ }^{33}$

The South China Sea is not only a legal dispute, but also considered by many as a security issue. Seen by how Indonesia's endeavor to materialize their maritime axis is accompanied by several attempts at enforcement of the law, rather than its judgment. One example is when in 2016, a chinese fishing boat was towed away by an Indonesian warship due to their violation of Indonesia's maritime territory. ${ }^{34}$ Another fact to add is that Indonesia's current maritime affairs and fisheries minister, Susi Pudjiastuti is sort of a hardline person in regards to Indonesia's maritime sovereignty. Blowing towed away ships and expressing her frustration to maritime violators is one of the trademark of her incumbency. These actions however, risk of alienating other ASEAN members if Indonesia does its part too unilaterally. Indonesia is in dire need of balancing its every act if they want their vision of a secured Indo-Pacific under a maritime axis to not be under fire.

This massive infrastructure undertaking by the current government of Indonesia may indeed prove to be its largest intake of foreign investment, however in a society where foreign assistance can be seen as an ammunition for offensive maneuvers in domestic politics, we need to view the threat of China in a different prism. Indonesian Sinophobia is still quite prominent in its society, ethnic chinese Indonesian citizens are still in a significant extent regarded as foreign in Indonesia and is without question would extend to 'indigineous', mainly Javanese, muslim male who are partnering with said 'chinese'. ${ }^{35}$ Whether the chinese in discussion are actually from China or a chinese descent, Indonesian

\footnotetext{
32 Pramesha Saha, “Indonesia’s 'soft balancing' against China,” Observer Research Foundation, 30 May, 2018, https://www.orfonline.org/expert-speak/41210-indonesia-soft-balancing-against-china/.

${ }^{33}$ Rizky Jaramaya, “ JK: Cina Investasi Oke, Tapi Jangan Bawa Banyak Tenaga Kerja,” Republika.co.id, 28

November, 2017, https://republika.co.id/berita/ekonomi/bisnis-global/17/11/28/p036rj440-jk-cina-investasi-oketapi-jangan-bawa-banyak-tenaga-kerja.

${ }^{34}$ Hannah Beech and Muktita Suhartono, "A 'Little Bit of a Nut Case' Who's Taking On China," The New York Times, 8 June, 2018, https://www.nytimes.com/2018/06/08/world/asia/indonesia-fishing-boats-chinapoaching.html.

35 Johannes Nugroho, "Why anti-Chinese sentiments persist in Indonesia," Today Online, 9 September, 2016, https://www.todayonline.com/commentary/why-anti-chinese-sentiments-persist-indonesia.
} 
society still have a vague hatred towards them, and it endangers even the slightest cooperation by the current administration to be interpreted as a concession to foreign powers. ${ }^{36}$

A summary of Indonesia's goal in this strategic goal can be argued to encompass ASEAN centrality, Indo-Pacific security, and the Maritime Axis doctrine. In ASEAN centrality, I believe that Indonesia must pursue it fully multilaterally in accordance with the framework of the ASEAN Community of 2025 with its entailed three pillars. Indonesia has even advocated an ASEAN patrol of the South China Sea, ${ }^{37}$ we can argue that this is one of Indonesia's effort to put ASEAN centrality in its maritime foreign policy. The Indo-Pacific aspect however is where India and Australia can assist Indonesia. With Australia's counterbalance and its closeness to the United States, we can see that it can provide ample military support even though it is only in the from of militarily flexing in joint exercises. India can also help Indonesia in the sense that the ever nearing ties between Modi's and Jokowi's government may prove to be a great asset in the future in combating China's relentless expansion in the region. Thus all of those help and emphasis would help Indonesia in finally achieving its visioned Maritime Axis through the balancing of foreign investment and national integrity.

\section{Conclusion: A Takeaway of the Triage}

The conclusion that I will present here will take inspiration from several points addressed by the panel of experts meeting in Brookings India back in 22 August 2018. In the discussion of the Indonesia-India-Australia trilateralism, the panel of experts come from various backgrounds. Dino Patti Djalal, the former Indonesian Deputy Foreign Minister gives his take on Indonesia's perspective. Peter Varghese delivers his insights on Australia's standing in this trilateralism as the former Australian Foreign Affairs Secretary. Shivshankar Menon as the former Indian Foreign Secretary and National Security Advisor is the one conveying the Indian perspective on the issue. I will also add my own previous point to compound the concluding remarks of this paper.

\footnotetext{
${ }^{36}$ Herdaru Purnomo, "Lagi-lagi Antek Asing, Jokowi: Emang Gampang Rebut Freeport?," CNBC Indonesia, 3 November, 2018, https://www.cnbcindonesia.com/news/20181103134659-4-40439/lagi-lagi-antek-asingjokowi-emang-gampang-rebut-freeport.

${ }^{37}$ Prashanth Parameswaran, "What's New About Indonesia's 'Push' for ASEAN South China Sea Patrols?," The Diplomat, 20 March, 2018, https://thediplomat.com/2018/03/whats-new-about-indonesias-push-for-aseansouth-china-sea-patrols/.
} 
In regards to Indonesia, we need to see that it is currently in the process of materializing its maritime dominance and superiority in the global context through the IndoPacific concept and its maritime axis doctrine. This is also with their ASEAN centrality in mind. India on the other hand, is trying its best to counter both the hegemonic contestation from its direct rival Pakistan and added with Chinese assistance. The problem is then gaining more weight from the lack of functioning regionalism in South Asia. In the context of Australia, we see a United States deputy that is almost as ruthless as the global hegemon. However we need to see an Australian government that is more included within the framework of its southeast asian partners. Jokowi's leadership of Indonesia has shown an increasing liking on ASEAN-Australia relations, that however cannot be the only aspect that Australia can rely on in regards to strengthening its ties with its northern neighbors. Those are, I believe, the obstacles of each Leviathans.

They also possess great potential in regards to the synergy that they can emit towards their common cause. Indonesia's ever-increasing prominence in the global economy and its continuous contribution to ASEAN may indeed realize the ASEAN Community in time and in turn would solidify and legitimize their regional hegemony. This is in the context of expanding Indonesia within the scope of ASEAN centrality. India would be able to challenge chinese expansion in regards to investments and financing in Indonesia and Australia, India would easily do this if Indonesia and Australia successfully do their part. This is of course while still maintaining a strategic observation towards Pakistan and the chinese expansion in South Asian politics ans economy. The new government leader Scott Morrison's track record of maintaining a strategic balance between the economic benefits of chinese trading and investment cooperation and the maintenance of national security may indeed supplement the triage with ample trilateral standing. Coupled with the fact that Australia can give the triage a significant amount of military support when needed.

All of those would be in the purpose of solidifying each of their respective regional hegemony. They do this due to the structural nature of the international system that require all of the three countries to comply with the current international architecture which is comprised of an arbitrarily drawn spheres of influence and regions. Regionalism might be important in maintaining a strategic advantage in their respective areas, however the maintenance of their regional superiority I believe is more important than the endeavor to construct a regional institution itself. With that said, I believe that each countries already respect the other's sphere of influence, and that in turn provide an ample baseline for this 
trilateral relationship to ensue. Again, the region based hegemony international architecture and the normative understanding of each countries' spheres of influence is what drive this trilateralism. That is all done for the sake of keeping the status quo against the revisionist power of the People's republic of China. 


\section{Bibliography}

Andreo Calonzo, "'I Need China': Duterte's Pivot to Beijing Shows Signs of Payoff," Bloomberg, 12 April, 2018, https://www.bloomberg.com/news/articles/2018-04-11/duterte-s-pivot-to-china-shows-some-signs-ofeconomic-payoff.

Angaindrakumar Gnanasagaran, "Behind Australia's invitation to join ASEAN," The ASEAN Post, 19 March, 2018, https://theaseanpost.com/article/behind-australias-invitation-join-asean.

Coco Feng, Qing Ying, Zeng Jia, Wang Liwei, "New Australian PM Has History of Blocking Chinese Investment," Caixin Global, 24 August, 2018, https://www.caixinglobal.com/2018-08-24/new-australian-pmhas-history-of-blocking-chinese-investment-101318546.html.

G. John Ikenberry, "The Rise of China and the Future of the West," Foreign Affairs, February, 2008, https://www.foreignaffairs.com/articles/asia/2008-01-01/rise-china-and-future-west.

Hannah Beech and Muktita Suhartono, "A 'Little Bit of a Nut Case' Who's Taking On China," The New York Times, 8 June, 2018, https://www.nytimes.com/2018/06/08/world/asia/indonesia-fishing-boats-chinapoaching.html.

Herdaru Purnomo, "Lagi-lagi Antek Asing, Jokowi: Emang Gampang Rebut Freeport?," CNBC Indonesia, 3 November, 2018, https://www.cnbcindonesia.com/news/20181103134659-4-40439/lagi-lagi-antek-asingjokowi-emang-gampang-rebut-freeport.

Jawad Falak, "Implacable Failures of the SAARC," Center For Strategic and Contemporary Research, 21 June, 2017, https://cscr.pk/explore/themes/politics-governance/implacable-failures-of-the-saarc/.

Jawad Falak, "INDIAN HEGEMONY: ROOTS OF SOUTH ASIAN CONFLICT," Strategem, 2016, http://www.stratagem.pk/setting-the-record-straight/indian-hegemony-roots-south-asian-conflict/.

Jayadeva Ranade, "SITUATION IN MALDIVES COULD POTENTIALLY FURTHER RAISE INDIACHINA TENSIONS," Centre for China Analysis \& Strategy, 19 February, 2018, https://ccasindia.org/Maldives.pdf.

Joanne Wallis, "Hollow hegemon: Australia's declining influence in the Pacific," East Asia Forum, 21 September, 2016, http://www.eastasiaforum.org/2016/09/21/hollow-hegemon-australias-declining-role-in-thepacific/.

Johannes Nugroho, "Why anti-Chinese sentiments persist in Indonesia," Today Online, 9 September, 2016, https://www.todayonline.com/commentary/why-anti-chinese-sentiments-persist-indonesia.

Kevin Rudd, "Are China and the US doomed to conflict? | Kevin Rudd -YouTube," TED, 1 April, 2015, https://www.youtube.com/watch?v=8XQ1onjXJK0.

Kirtika Suneja, "Australia committed to concluding a high-quality FTA with India, says Australian High Commissioner," The Economic Times, 8 August, 2018,

https://economictimes.indiatimes.com/news/economy/foreign-trade/australia-committed-to-concluding-a-highquality-fta-with-india-says-australian-high-commissioner/articleshow/65328506.cms.

Lily Kuo and Niko Kommenda, "What is China's Belt and Road Initiative?," The Guardian, https://www.theguardian.com/cities/ng-interactive/2018/jul/30/what-china-belt-road-initiative-silk-roadexplainer.

Mercy A. Kuo, "China-Pakistan Relations: Challenging US Global Leadership,” The Diplomat, 30 May, 2018, https://thediplomat.com/2018/05/china-pakistan-relations-challenging-us-global-leadership/.

Nik Luqman, "Is ASEAN Consensus A Blessing or Curse - or Both?," ASEAN News, 19 July, 2015, http://www.aseannews.net/asean-consensus-blessing-curse/. 
Partha S Ghosh, "Cooperation in South Asia: Region without Regionalism," Economic \& Political Weekly, 6 August, 2018, https://www.epw.in/journal/2016/32/special-articles/region-without-regionalism.html.

Pramesha Saha, “Indonesia's ‘soft balancing' against China,” Observer Research Foundation, 30 May, 2018, https://www.orfonline.org/expert-speak/41210-indonesia-soft-balancing-against-china/.

Prashanth Parameswaran, "What's New About Indonesia's 'Push' for ASEAN South China Sea Patrols?," The Diplomat, 20 March, 2018, https://thediplomat.com/2018/03/whats-new-about-indonesias-push-for-asean-southchina-sea-patrols/.

Rizky Jaramaya, “ JK: Cina Investasi Oke, Tapi Jangan Bawa Banyak Tenaga Kerja,” Republika.co.id, 28 November, 2017, https://republika.co.id/berita/ekonomi/bisnis-global/17/11/28/p036rj440-jk-cina-investasi-oketapi-jangan-bawa-banyak-tenaga-kerja.

Sanjeev Miglani and Mohamed Junayd, "After building spree, just how much does the Maldives owe China?," Reuters, 23 November, 2018, https://www.reuters.com/article/us-maldives-politics-china/after-building-spreejust-how-much-does-the-maldives-owe-china-idUSKCN1NS1J2.

William H. Frederick and Thomas R. Leinbach, "Southeast Asia," Encyclopaedia Britannica, https://www.britannica.com/place/Southeast-Asia.

Wang Xiangwei, "ANTI-CHINA HYSTERIA VS NEED FOR TRADE: AUSTRALIA STRUGGLES WITH A RISING BEIJING," South China Morning Post, 4 August, 2018, https://www.scmp.com/weekasia/opinion/article/2157933/anti-china-hysteria-vs-need-trade-australia-struggles-rising.

Zee Ayurveda, "After China, maldives ropes in Pakistan for Power," The Times of India, 6 July, 2018, https://timesofindia.indiatimes.com/world/south-asia/after-china-maldives-ropes-in-pakistan-forpower/articleshow/64889956.cms.

"'Any friend of Modi's is a traitor': Anti-India rhetoric played a role in Pakistan elections," scroll.in, https://scroll.in/article/888135/any-friend-of-modis-is-a-traitor-the-role-anti-india-rhetoric-played-in-pakistanselections.

"Australia and Vanuatu to negotiate security pact to head off China expansion," The Telegraph, 22 June 2018, https://www.telegraph.co.uk/news/2018/06/25/australia-vanuatu-negotiate-security-pact-head-china-expansion/

"Australia plans naval base in Papua New Guinea to curb China's Pacific Influence," South China Morning Post, 20 September, 2018, https://www.scmp.com/news/asia/australasia/article/2164982/australia-plans-navalbase-papua-new-guinea-curb-chinas.

“Australian Military in South China Sea," SBS NEWS, 1 October, 2018, https://www.sbs.com.au/news/australian-military-in-south-china-sea.

“Australia warns against US-China tensions," The Strait Times, 1 November, 2018,

https://www.straitstimes.com/asia/australianz/australia-warns-against-us-china-tensions.

"Huawei and ZTE handed 5G network ban in Australia," BBC News, 23 August, 2018, https://www.bbc.com/news/technology-45281495.

"Implacable Failures of the SAARC," Centre for Strategic and Contemporary Research, 21 June, 2017, https://cscr.pk/explore/themes/politics-governance/implacable-failures-of-the-saarc/.

“'I think we both get it': Scott Morrison professes admiration for Trump," The Guardian, 17 September, 2018, https://www.theguardian.com/australia-news/2018/sep/17/i-think-we-both-get-it-scott-morrison-professesadmiration-for-trump.

“Pertama Kali, Presiden Jokowi Dukung Australia Masuk ASEAN,” Tempo.co, 16 March, 2018, https://dunia.tempo.co/read/1070224/pertama-kali-presiden-jokowi-dukung-australia-masuk-asean. 
“PM Narendra Modi’s visit a grand success, says Sri lanka minister,” Hindustan Times, 17 May, 2017, https://www.hindustantimes.com/india-news/pm-narendra-modi-s-visit-a-grand-success-says-sri-lankaminister/story-4rair1RfTsAkocLVPeAG8N.html.

“The Potential of Intra-regional Trade for South Asia," The World Bank, 24 May, 2018,

http://www.worldbank.org/en/news/infographic/2016/05/24/the-potential-of-intra-regional-trade-for-south-asia 